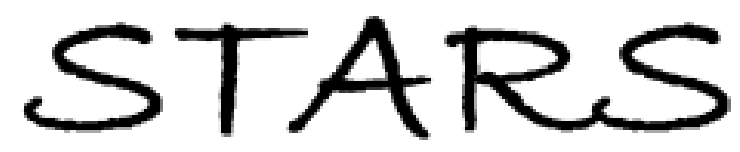

University of Central Florida

STARS

$1-1-2005$

\title{
Study of molybdenum back contact layer to achieve adherent and efficient CIGS2 absorber thin-film solar cells
}

Ankur A. Kadam

University of Central Florida

Neelkanth G. Dhere

University of Central Florida

Paul Holloway

Evan Law

Find similar works at: https://stars.library.ucf.edu/facultybib2000

University of Central Florida Libraries http://library.ucf.edu

This Article; Proceedings Paper is brought to you for free and open access by the Faculty Bibliography at STARS. It has been accepted for inclusion in Faculty Bibliography 2000s by an authorized administrator of STARS. For more information, please contact STARS@ucf.edu.

\section{Recommended Citation}

Kadam, Ankur A.; Dhere, Neelkanth G.; Holloway, Paul; and Law, Evan, "Study of molybdenum back contact layer to achieve adherent and efficient CIGS2 absorber thin-film solar cells" (2005). Faculty Bibliography 2000s. 5319.

https://stars.library.ucf.edu/facultybib2000/5319

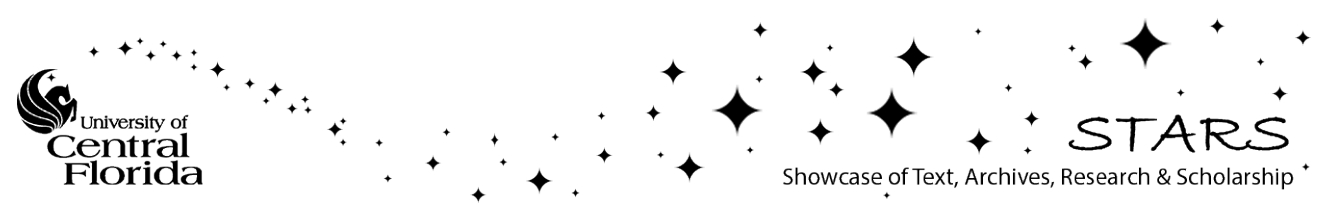




\section{Study of molybdenum back contact layer to achieve adherent and efficient CIGS2 absorber thin-film solar cells}

Ankur A. Kadam, Neelkanth G. Dhere, Paul Holloway, and Evan Law

Citation: Journal of Vacuum Science \& Technology A 23, 1197 (2005); doi: 10.1116/1.1889440

View online: https://doi.org/10.1116/1.1889440

View Table of Contents: https://avs.scitation.org/toc/jva/23/4

Published by the American Vacuum Society

\section{ARTICLES YOU MAY BE INTERESTED IN}

Preparation and optimization of a molybdenum electrode for CIGS solar cells AIP Advances 6, 115210 (2016); https://doi.org/10.1063/1.4967427

Stress, strain, and microstructure of sputter-deposited Mo thin films Journal of Applied Physics 70, 4301 (1991); https://doi.org/10.1063/1.349108

The role of buffer layers and double windows layers in a solar cell CZTS performances AIP Conference Proceedings 1758, 030034 (2016); https://doi.org/10.1063/1.4959430

Band tailing and efficiency limitation in kesterite solar cells Applied Physics Letters 103, 103506 (2013); https://doi.org/10.1063/1.4820250

On the kinetics of $\mathrm{MoSe}_{2}$ interfacial layer formation in chalcogen-based thin film solar cells with a molybdenum back contact

Applied Physics Letters 102, 091907 (2013); https://doi.org/10.1063/1.4794422

Detailed Balance Limit of Efficiency of $p-n$ Junction Solar Cells Journal of Applied Physics 32, 510 (1961); https://doi.org/10.1063/1.1736034

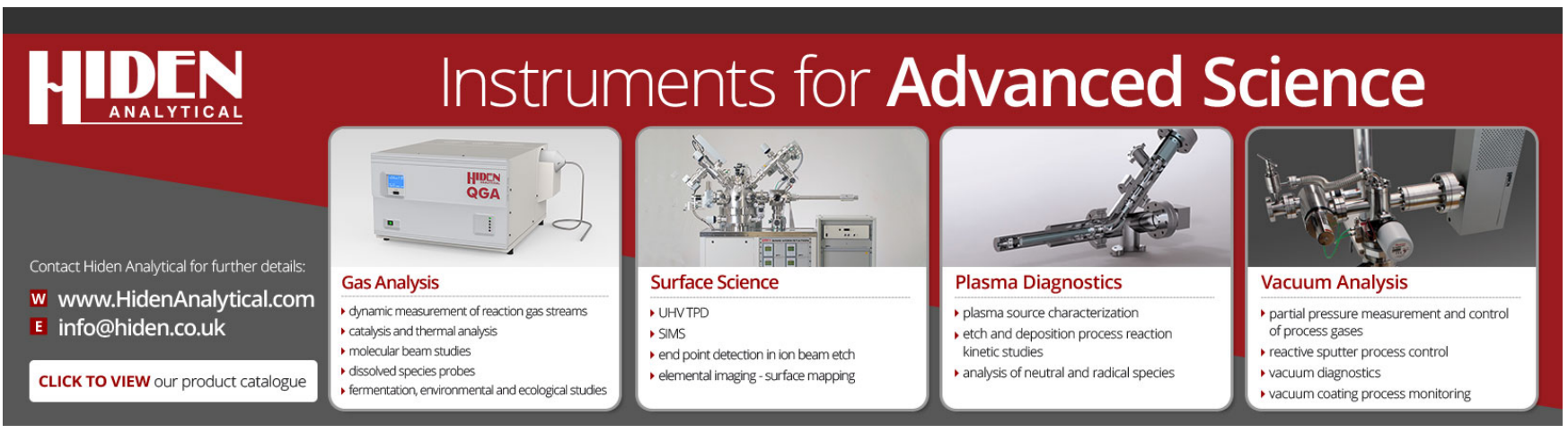




\title{
Study of molybdenum back contact layer to achieve adherent and efficient CIGS2 absorber thin-film solar cells
}

\author{
Ankur A. Kadam ${ }^{\text {a) }}$ and Neelkanth G. Dhere ${ }^{\text {b) }}$ \\ Florida Solar Energy Center, University of Central Florida, 1679 Clearlake Road, Cocoa, Florida 32922 \\ Paul Holloway and Evan Law \\ Department of Materials Science, University of Florida, Gainesville, Florida 32611
}

(Received 3 November 2004; accepted 14 February 2005; published 28 June 2005)

\begin{abstract}
Molybdenum is used as back contact layer in I-III-VI 2 compound thin-film solar cells. Mo film was sputter deposited on 125-mm-diameter $\mathrm{Si}$ wafer having 100 orientation using dc magnetron sputtering. Films with similar parameters were also deposited on $2.5 \mathrm{~cm} \times 10 \mathrm{~cm}$ soda-lime glass for studying the adhesion to the substrate and chemical reactivity of molybdenum with $\mathrm{H}_{2} \mathrm{~S}$ gas at $475^{\circ} \mathrm{C}$ for $20 \mathrm{~min}$. Mo being refractory material develops stresses. It is essential to deposit stress-free and relatively inert Mo films in order to achieve well adherent and highly efficient $\mathrm{CuIn}_{1-x} \mathrm{Ga}_{x} \mathrm{~S}_{2}$ absorber thin film solar cells on flexible metallic foil and glass substrates. Earlier studies have shown that films deposited at sputtering power of $300 \mathrm{~W}$ and $0.3 \times 10^{-3}$ Torr working argon pressure develop compressive stress, while the films deposited at $200 \mathrm{~W}$ and $5 \times 10^{-3}$ Torr pressure develop tensile stress. Four sets of experiments were carried out to achieve optimum deposition cycle to deposit stress-free Mo. In the first experiment, Mo thickness of $138 \mathrm{~nm}$ was deposited at $300 \mathrm{~W}$ power and $0.3 \times 10^{-3}$ Torr pressure. In the second experiment Mo thickness of $127 \mathrm{~nm}$ was deposited at power of $200 \mathrm{~W}$ and pressure of $5 \times 10^{-3}$ Torr. Two more experiments were carried out by using alternate layers to reduce the overall stress. In a third experiment, two high power cycles were sandwiched between three low power cycles with total film thickness of $330 \mathrm{~nm}$. In a fourth experiment two low power cycles were sandwiched between three high power cycles resulting in effective thickness of $315 \mathrm{~nm}$. This article describes the wafer bending analysis for stress measurement, x-ray diffraction for crystal quality, scanning electron microscopy for surface morphology and Auger electron spectroscopy for the extent of sulfur diffusion in Mo layer. (C) 2005 American Vacuum Society. [DOI: 10.1116/1.1889440]
\end{abstract}

\section{INTRODUCTION}

Molybdenum is one of the most important materials used as back ohmic contact for $\mathrm{CuIn}_{1-x} \mathrm{Ga}_{x} \mathrm{Se}_{2-y} \mathrm{~S}_{y}$ (CIGSS) thin film solar cells. A variety of metal/ $\mathrm{CuInSe}_{2}$ (CIS) contacts have been investigated, including $\mathrm{Mo}, \mathrm{Pt}, \mathrm{Au}, \mathrm{Au} / \mathrm{Be}, \mathrm{Al}, \mathrm{Ni}$, $\mathrm{Ag}$, and $\mathrm{Cu}$. These studies show that $\mathrm{Pt}, \mathrm{Ni}, \mathrm{Au}$, and $\mathrm{Mo}$ all form fairly reproducible, low-resistance contacts to CIS. When annealed at elevated temperatures $\mathrm{Au}$ and $\mathrm{Pt}$ show significant diffusion into the CIS, ${ }^{1}$ while molybdenum and nickel contacts seem to improve with high-temperature treatment. ${ }^{2}$ Other evidence shows that both molybdenum and tungsten films deposited on CIS interdiffuse in the bulk at $600{ }^{\circ} \mathrm{C}^{3}$ The contact properties of CIS films formed at high temperatures $\left(600{ }^{\circ} \mathrm{C}\right.$ and above) on metallic thin films are likely to be quite different. ${ }^{3}$ Moreover, for polycrystalline CIS solar cells, the metallic back contact forms the substrate upon which the absorber layer is formed. Because of its relative stability at the processing temperatures, resistance to alloying with $\mathrm{Cu}$ and indium, and its low contact resistance to CIS, molybdenum has emerged as the dominant choice for the back contact layer to CIS and CIGSS solar cells. ${ }^{4}$ Mo-

\footnotetext{
a)Electronic mail: akadam@fsec.ucf.edu

${ }^{b)}$ Author to whom correspondence should be addressed; electronic mail: dhere@fsec.ucf.edu
}

lybdenum when deposited using dc magnetron technique exhibits a correlation between sputtering gas pressure (argon) and developed residual stress. Earlier studies have shown that films deposited at high power and low argon pressure (high power) are generally found to be in compressive stress, while those deposited with low power and high pressures (low power) are found to be in tensile stress. Gross stress may be determined by visual inspection in that highly compressed films tend to buckle up, frequently in zigzag patterns, whereas films under extreme tensile stress develop a system of stress lines that look like scratches. ${ }^{5}$ It is suggested that such stress reversals are dependent on energetic bombardment by reflected neutrals and/or sputtered atoms. The working gas pressure is expected to moderate the flux and energy of these particles. At relatively low pressures, the arriving atom has high kinetic energy and the resulting film has dense microstructure, experiencing compressive stress. This compressive stress is explained by atomic peening caused by the impact of energetic particles. At relatively high pressures, less energy is provided to the film because of scattering and the resulting film exhibits an open porous microstructure. Interatomic attractive forces producing tensile stress can act most effectively in such structures. This article presents the stress, morphology and composition analysis carried out using wafer bending technique, x-ray diffraction (XRD), scanning electron microscopy (SEM) and Auger electron micros- 
TABLE I. Loads applied to make foil flat.

\begin{tabular}{lcc}
\hline \hline \multicolumn{1}{c}{$\begin{array}{c}\text { Power/argon } \\
\text { pressure }\end{array}$} & $\begin{array}{c}\text { Height of } \\
\text { curvature }\end{array}$ & Loads applied \\
\hline $300 \mathrm{~W} / 0.3 \times 10^{-3}$ & $0.88 \mathrm{~mm}$ & $450 \mathrm{mg}$ \\
$\begin{array}{l}\text { Torr }(\text { cycle A) } \\
200 \mathrm{~W} / 5 \times 10^{-3}\end{array}$ & $0.48 \mathrm{~mm}$ & $130 \mathrm{mg}$ \\
$\begin{array}{l}\text { Torr }(\text { cycle B) } \\
\text { Alternate cycles } \\
\text { (cycle C and D) }\end{array}$ & Flat film & $\ldots$ \\
\hline \hline
\end{tabular}

copy (AES) to obtain stress-free, well adherent and chemically inert molybdenum back contact layers.

\section{EXPERIMENT}

Molybdenum deposition was carried out by dc magnetron sputtering in a vacuum chamber with base pressure of 3 $\times 10^{-6}$ Torr using a combination of mechanical pump and cryo pump. ${ }^{6}$ Depositions were carried out from a Mo target of dimensions $30 \mathrm{~cm} \times 10 \mathrm{~cm}$. The distance between the target and substrate was maintained at $6 \mathrm{~cm}$ throughout for all depositions. The substrates were moved linearly along $10 \mathrm{~cm}$ width of the target with the help of a PC-controlled stepper motor. The thickness variation was in the range of $\pm 3 \%$ along the $30 \mathrm{~cm}$ length of the target. Earlier, preliminary experiments were carried out on 25 - $\mu$ m-thick titanium foil to obtain qualitative information about the stresses developed under various parameters of deposition. Thin flat strips of titanium foil of dimension $1 \mathrm{~cm} \times 15 \mathrm{~cm}$ were attached to a glass substrate along the $30 \mathrm{~cm}$ length of the target gluing them with vacuum compatible tape only at the two ends. The length and the corresponding bend displayed by the titanium foil were along the $30 \mathrm{~cm}$ length. Depending on the stress developed, the nature of bend in the foil was either convex or concave. Later to obtain quantitative information, wafer bending and XRD analysis were carried out. Mo depositions were carried out on $125 \mathrm{~mm}$ silicon wafers having 100 orientation. The thickness of the silicon wafers was $500 \mu \mathrm{m}$ and polished on one side. Measurement of stress was carried out by measuring the change in curvature of the wafer using a Flexus (Tencor FLX-2320) surface profilometer. Initially, the curvatures of the uncoated wafers were measured. These values were used as reference for measuring the change in

TABLE II. Nature and amount of stress buildup during selected deposition cycles.

\begin{tabular}{cccc}
\hline \hline Cycle type & $\begin{array}{c}\text { Thickness } \\
(\mathrm{nm})\end{array}$ & $\begin{array}{c}\text { Stress along } 30 \mathrm{~cm} \\
\text { length of target } \\
(\mathrm{MPa})\end{array}$ & $\begin{array}{c}\text { Stress along } 10 \mathrm{~cm} \\
\text { width of target } \\
(\mathrm{MPa})\end{array}$ \\
\hline A & 127 & 300 (tensile) & 20.5 (compressive) \\
$\mathrm{A}^{\prime}$ (repeated) & 260 & 69 (compressive) & 330 (compressive) \\
B & 138.8 & 91 (compressive) & 100 (compressive) \\
$\mathrm{B}^{\prime}$ (repeated) & 300 & 120 (compressive) & 162 (compressive) \\
C & 330 & 35.8 (tensile) & 18.5 (compressive) \\
D & 315.3 & 103.7 (tensile) & 19.6 (compressive) \\
\hline \hline
\end{tabular}

TABLE III. Data collected from XRD patterns of the films.

\begin{tabular}{cccccc}
\hline \hline & $\begin{array}{c}\text { Mo(110) } \\
\text { intensity } \\
\text { (counts) }\end{array}$ & $\begin{array}{c}\text { FWHM } \\
\text { Mo(110) }\end{array}$ & $\begin{array}{c}\mathrm{Fe}(110) / \\
\mathrm{Mo}(110)\end{array}$ & $\begin{array}{c}\text { Interplanar } \\
d(110) \AA\end{array}$ & $\begin{array}{c}\text { Lattice } \\
\text { parameter "a" } \\
\AA\end{array}$ \\
\hline $\mathrm{C}$ & 81 & 1.54 & $34.5 \%$ & 2.25 & 3.18 \\
$\mathrm{D}$ & 85 & 1.26 & $24.7 \%$ & 2.24 & 3.167 \\
\hline \hline
\end{tabular}

curvature and thereby calculating the stress in the deposited film. Four deposition cycles were selected for the purpose of this experiment. Argon was used as a sputtering gas and its flow rate, and hence its pressure, was varied with a mass flow controller. Silicon wafers used for deposition were mounted in the vacuum chamber on the day before deposition. The wafer was kept in $5 \times 10^{-6}$ Torr vacuum overnight to ensure a clean surface. Based on the parameters, such as power, pressure and time, four deposition cycles were designed. Cycle A, termed High Power, corresponded to the deposition parameters of $300 \mathrm{~W}, 0.3 \times 10^{-3}$ Torr and 5 min $52 \mathrm{~s}(11 \mathrm{~s}$ per $1.25 \mathrm{~cm}$ linear movement of substrate over target). The corresponding voltage values were in the range of 328-332 V and current values were in the range of 0.89-0.9 A. Cycle B, termed Low Power, corresponded to the deposition parameters of $200 \mathrm{~W}$ and $5 \times 10^{-3}$ Torr operating pressure and total deposition time of $11 \mathrm{~min} 44 \mathrm{~s}$. The applied voltage was in the range of $270-280 \mathrm{~V}$ and current was in the range of $0.7-0.73 \mathrm{~A}$. The deposition duration of $22 \mathrm{~s}$ per $1.25 \mathrm{~cm}$ movement of substrate was selected in order to ensure complete coverage of the substrate while moving over the target as well as to achieve particular thickness of the film. Cycle A resulted in a film thickness of $138 \mathrm{~nm}$ while cycle B resulted in film thickness of $127 \mathrm{~nm}$. The other two cycles were the combination of above mentioned cycles. Cycle $\mathrm{C}$ corresponded to the deposition sequence of two high power cycles sandwiched alternately between three low power cycles. The deposition was carried out for a total period of $23 \mathrm{~min}$ and $28 \mathrm{~s}$ with resulting film thickness of $330 \mathrm{~nm}$. Cycle D corresponded to the deposition sequence of two low power cycles sandwiched alternately between three high power cycles. The total deposition time was $20 \mathrm{~min}$ and $32 \mathrm{~s}$ resulting in thickness of $315 \mathrm{~nm}$. Along with the silicon wafer, a $2.5 \mathrm{~cm} \times 10 \mathrm{~cm}$ soda-lime glass piece was also mounted for measuring the thickness of the film, to check adhesion using simple adhesive tape and for morphology and composition analyses using XRD, SEM and AES.

\section{RESULTS AND DISCUSSION}

Initially simple bending foil technique was used to estimate the amount of stress present in the foils. This was a crude approach for qualitatively understanding of the stress buildup by varying the deposition parameters. Loads were applied to the concave and convex region of the foil and weight required to make the foil flat similar to its position prior to deposition was measured. The required load, height of curvature and the stress developed in the film are provided in Table I. 


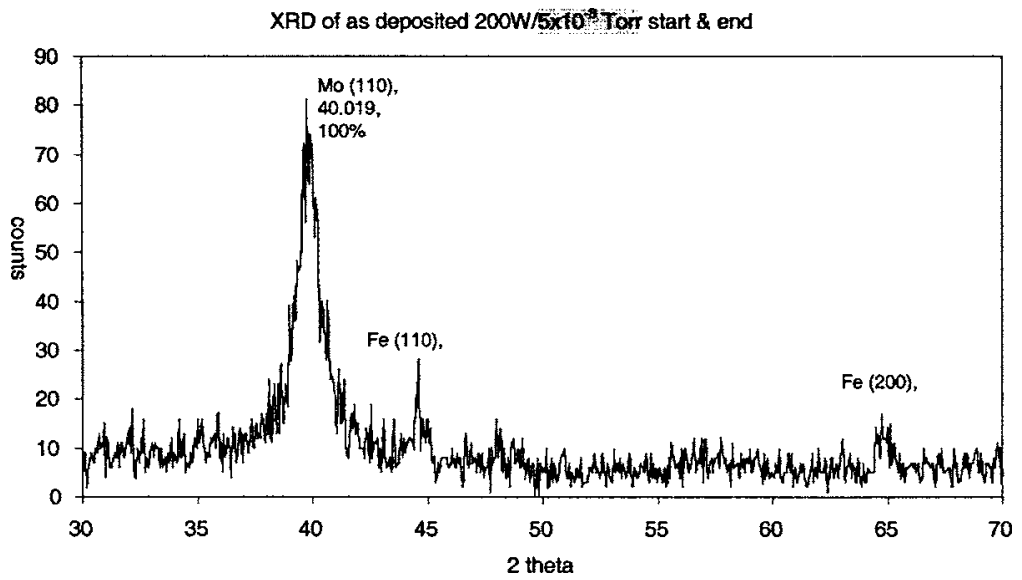

FIG. 1. XRD pattern of as-deposited molybdenum film, from cycle $\mathrm{C}$.

From the data of applied loads as well as the curvature of the foil it was observed that the stress developed during cycle A was comparatively more than that developed during cycle B. From the amount of load required for flattening the foil, it was observed that the stress developed in cycle A was approximately three times that of stress developed in cycle B. Depositions carried out using cycle C and D showed a flat feature indicating very small residual stress. As mentioned earlier, for quantitative measurement wafer-bending technique was used. The stress in the film was calculated from the following equation: ${ }^{7}$

$$
\sigma=\frac{[E /(1-v)]}{\left[h^{2} / 6 R t\right]},
$$

where

$\sigma$ is the film stress $(\mathrm{Pa})$;

$E /(1-\nu)$ is the biaxial elastic modulus of the substrate (1.805E11 Pa for $100 \mathrm{Si}$ );

$h$ is the substrate thickness $(m)$;

$t$ is the film thickness $(m)$; and

$R$ is the radius of the curvature $(m)$ of the substrate.

Table II summarizes the stress value in the individual high power and low power cycles as well as in the combination cycles.
The high power cycle (cycle A) measured $300 \mathrm{MPa}$ tensile stress while low power cycle (cycle B) measured $91 \mathrm{MPa}$ compressive stress along $30 \mathrm{~cm}$ length of the target. On the other hand, earlier work and some publications ${ }^{8}$ report the nature of stress to be compressive for high power cycle and tensile for low power cycle. The deposition process for cycles A and B was repeated with higher thicknesses of $260 \mathrm{~nm}$ for cycle $\mathrm{A}^{\prime}$ and $300 \mathrm{~nm}$ for cycle $\mathrm{B}^{\prime}$. Stress values obtained along $30 \mathrm{~cm}$ length of target were $120 \mathrm{MPa}$ (compressive) and $69 \mathrm{MPa}$ (compressive) respectively. These values were not consistent with the earlier reported values for lower thickness. The above experiments will be repeated to determine the consistency of the results within lower and higher thicknesses, also the inconsistency between stress values of lower and higher thickness will be resolved with further experimentation using thinner silicon wafers. The stress values for cycle $\mathrm{C}$ were comparatively lower in both the directions over that observed in cycle D, suggesting the benefits of using cycle $\mathrm{C}$ for depositing Mo back contact.

X-ray diffraction was carried out to measure the total strain in the lattice created due to sputter deposition during cycles $\mathrm{C}$ and D. Figure 1 represents the XRD pattern of film deposited using cycle $\mathrm{C}$, while Fig. 2 represents the XRD

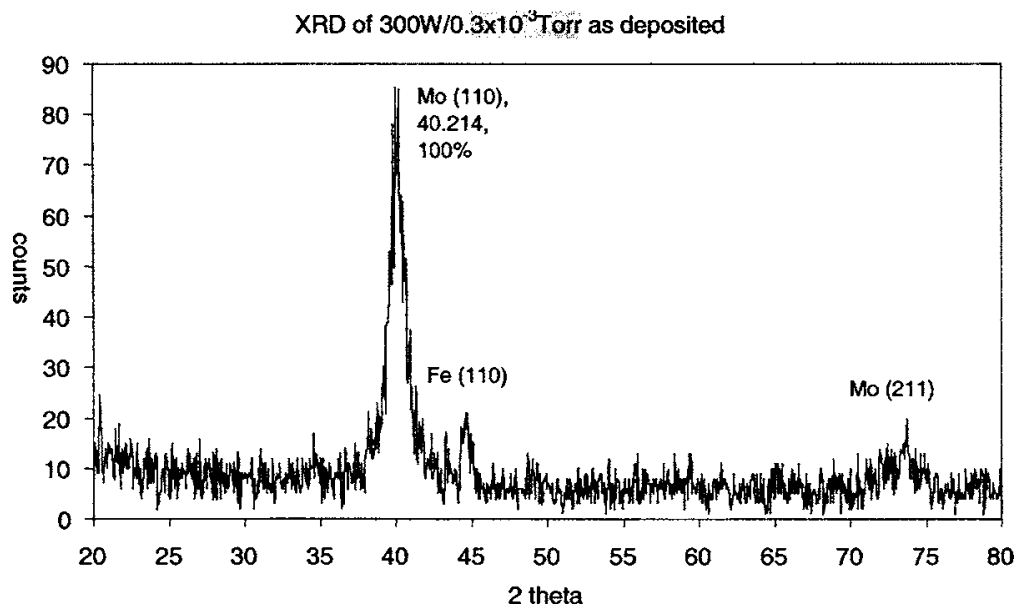

FIG. 2. XRD pattern of as-deposited molybdenum film, from cycle $\mathrm{D}$. 
TABLE IV. Sheet resistance and adhesion observations.

\begin{tabular}{ccc}
\hline \hline Cycles & $\begin{array}{c}\text { Sheet resistance } \\
(\Omega / \mathrm{sq} .)\end{array}$ & Adhesion observation \\
\hline A $(127 \mathrm{~nm})$ & 3.32 & Well adherent \\
$\mathrm{A}^{\prime}(260 \mathrm{~nm})$ & 2.20 & Well adherent \\
B $(138 \mathrm{~nm})$ & 13.5 & Well adherent \\
$\mathrm{B}^{\prime}(300 \mathrm{~nm})$ & 17.5 & Well adherent \\
$\mathrm{C}(330 \mathrm{~nm})$ & 2.20 & Peeled off \\
$\mathrm{D}(315 \mathrm{~nm})$ & 1.46 & Well adherent \\
\hline \hline
\end{tabular}

pattern obtained from film deposited using cycle D. Table III summarizes the analysis of the data obtained from the plot.

The lattice parameter of powdered and annealed molybdenum is $3.16 \AA$. The amount of induced strain can be computed using the simple relation

$$
\text { Strain } \%=\frac{\Delta a}{a} \times 100 \text {. }
$$

Strain induced by cycle $\mathrm{C}=0.63 \%$, cycle $\mathrm{D}=0.22 \%$.

From the values of induced strain, intensity, Fe (110) to Mo (110) peak intensity ratios and full width at half maximum (FWHM) it can be concluded that the film deposited, starting and ending with $300 \mathrm{~W} / 0.3 \times 10^{-3}$ Torr (cycle D), appears more crystalline as well as comparatively denser.

Sheet resistance measurements were carried out using four-point probe measurement technique on the films deposited in all cycles at four different locations per wafer at an identical position for each wafer. Adhesion of the film to the substrate was studied by simple adhesive tape test. Adhesive tape strips of same lengths were glued on the wafer and stripped with approximately equal amount of force. The film deposited in cycle $\mathrm{C}$ peeled off completely from $\mathrm{Mo} /$ substrate interface, while it remained adherent in other cycles. Sheet resistance values and adhesion observations are summarized in Table IV. Though the stress in the film was less as seen from wafer bending analysis, failure occurred probably because the first film in contact with substrate was less compact. Similar effect was not observed for film in cycle $\mathrm{B}$ because the film thickness in cycle $\mathrm{C}$ was higher as compared to the film thickness in cycle B. Small pieces of dimension $1 \mathrm{~cm} \times 1 \mathrm{~cm}$ were cut from the films deposited on glass substrate and sulfurized at $475{ }^{\circ} \mathrm{C}$ for 20 minutes to see the reactivity of Mo film. The films turned purple and energy dispersive spectroscopy revealed the presence of sulfur in all the films, indicating reactivity of Mo in sulfur atmosphere at operating temperature. The extent of sulfur incorporation in the film was analyzed by AES in conjunction with argon ion sputtering. Figure 3 shows the depth profile of elemental composition in individual films. It was observed that the sulfur diffused to a depth of $25 \mathrm{~nm}$ [Fig. 3(a)] in high power cycle A while it diffused to a depth of $35 \mathrm{~nm}$ [Fig. $3(b)]$ in the low power cycle B. This was expected as the film deposited in cycle A was more compact over that deposited in cycle B. Sulfur diffusion depth in Mo film of cycle $\mathrm{C}$ was $25 \mathrm{~nm}$ [Fig. 3(c)] and that by cycle D was $15 \mathrm{~nm}$ [Fig. 3(d)]. The results for cycles $\mathrm{C}$ and $\mathrm{D}$ can be justified as the top surface layer in cycle D was more compact than that of cycle C. Since it was desired to have minimum incorporation of sulfur in Mo film, it was concluded that Mo deposition sequence in cycle $\mathrm{D}$ is more suitable for back contact deposition.

Morphology of the films deposited at different combinations of operating conditions (power and pressure) was also studied by scanning electron microscopy (SEM). High power cycle A and low power cycle B films were independently deposited on glass substrates. The film deposited using cycle A was densely packed and showed less porosity [Fig. 4(a)]. This resulted in a decrease in film resistivity; the film deposited using cycle B had porous (fish-like) grain morphology and significant intergranular voids [Fig. 4(b)]. The higher resistivity was a direct result of this sputter-induced porosity. Figures 4(c) and 4(d) indicated compact morphology for cycles $\mathrm{C}$ and $\mathrm{D}$. It is interesting to note that the morphology in cycle $\mathrm{C}$ appears comparatively rougher than that in cycle D. This is expected as cycle C contains three cycles of porous films as shown in Fig. 4(b) while cycle D contains three

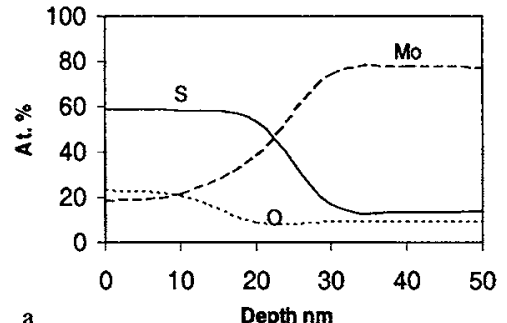

a

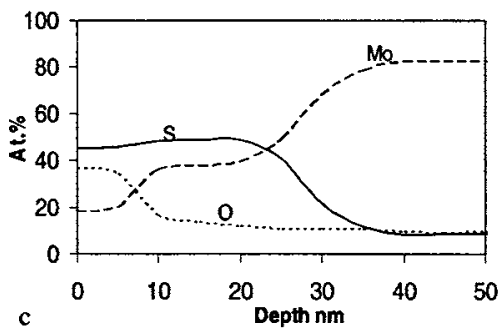

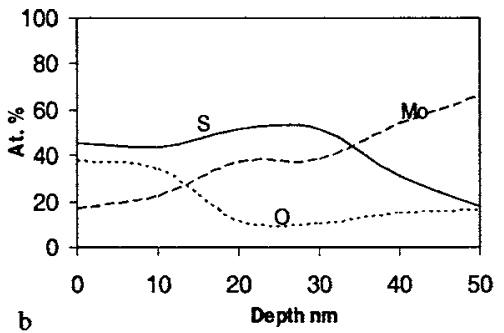

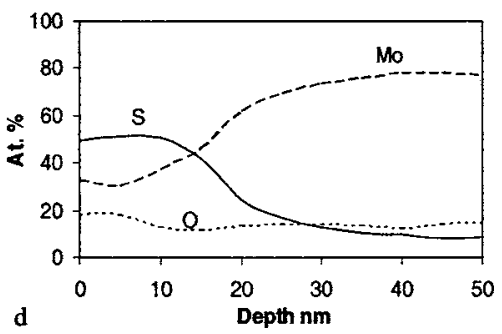

FIG. 3. (a), (b), (c), (d). AES depth profiling showing sulfur incorporation in Mo films. 


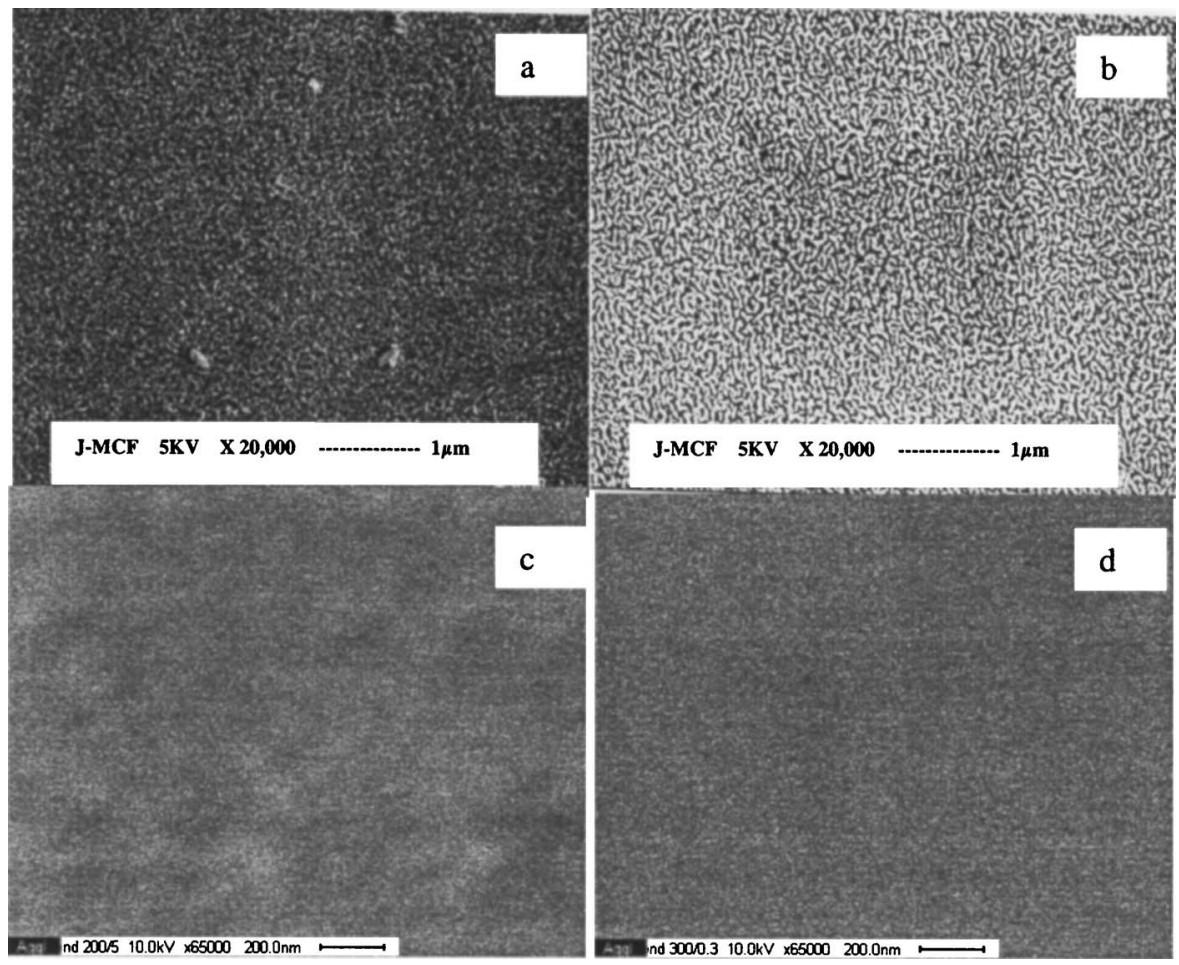

FIG. 4. (a) SEM micrograph of sample deposited at $300 \mathrm{~W} / 0.3 \times 10^{-3}$ Torr at $20000 \mathrm{X}$, (b) deposited at $200 \mathrm{~W} / 5$ $\times 10^{-3}$ Torr at $20000 \mathrm{X},(\mathrm{c})$ and (d) micrograph of low power and high power cycles at $65000 \mathrm{X}$.

cycles of comparatively denser structure as shown in Fig. 4(a). On the basis of SEM observations and resistivity values it was concluded to use cycle $\mathrm{D}$, as it provides compact, uniform and less resistive Mo film as back contact. These observations support the argument made from XRD analysis.

\section{CONCLUSIONS}

The overall conclusion for the selection of deposition cycle for Mo back contact was made taking into consideration the observations made in individual study. Wafer bending technique suggested that the cycle $\mathrm{C}$ composed of two layers deposited at $300 \mathrm{~W} / 0.3 \times 10^{-3}$ Torr sandwiched between three layers of $200 \mathrm{~W} / 5 \times 10^{-3}$ Torr develops comparatively lower stress. XRD, SEM, AES, adhesion and sheet resistance measurement suggested the film deposited in cycle D was crystalline, compact, inert, well adherent to the substrate and less resistive compared to the one deposited in cycle $\mathrm{C}$. The overall stress in the film deposited in cycle D can be reduced by depositing one more layer of Mo at $200 \mathrm{~W} / 5 \times 10^{-3}$ Torr. It is therefore recommended to use cycle D, composed of two layers deposited at $200 \mathrm{~W} / 5$ $\times 10^{-3}$ Torr sandwiched between three layers deposited at $300 \mathrm{~W} / 0.3 \times 10^{-3}$ Torr as the sputtering cycle for depositing Mo back contact layer. From a commercial production stand- point, a process involving six cycles is not advisible. The entire six layer sequence will be summed up in three layers. The first and third layer will be deposited by high power cycle with thicknesses corresponding to total thickness of three individual high power cycles $(300 \mathrm{~W} / 0.3$ $\times 10^{-3}$ Torr). The middle layer will be deposited by low power cycle with thickness equal to total thickness of three individual low power $\left(200 \mathrm{~W} / 5 \times 10^{-3}\right.$ Torr $)$ cycles.

\section{ACKNOWLEDGMENT}

This work was supported by the U.S. Department of Energy through the NREL Thin-Film Partnership.

${ }^{1}$ S. Ashour, A. H. Moutinho, R. Matson, and F. Abou-Elfotouh, Thin Solid Films 226, 129 (1993).

${ }^{2}$ I. Moons, J. Electron. Mater. 22, 275 (1993).

${ }^{3}$ S. Raud and M. A. Nicolet, Thin Solid Films 201, 361 (1991).

${ }^{4}$ K. Granath, A. Rockett, M. Bodegard, C. Nender, and L. Stolt, 13th European Photovoltaic Solar Energy Conference, Nice, France, 23-27 October 1995 (Stephens \& Associates, Felmersham, 1995), p. 1983.

${ }^{5}$ J. H. Scofield, A. Duda, D. Albin, B. L. Ballard, and P. K. Predecki, Thin Solid Films 260, 26 (1995).

${ }^{6}$ N. G. Dhere, S. R. Ghongadi, M. B. Pandit, A. H. Jahagirdar, and D. Scheiman, Prog. Photovoltaics 10, 407 (2002).

${ }^{7}$ W. C. Young, Roark's Formulas for Stress and Strain, 6th ed. (McGrawHill, New York, 1989).

${ }^{8}$ M. Itoh, M. Hori, and S. Nadahara, J. Vac. Sci. Technol. B 9, 149 (1991). 